\title{
Freshman Engineering Students At-Risk Of Non-Matriculation: Self-Efficacy For Academic Learning
}

\author{
Jeremy V. Ernst, Ed.D., Virginia Tech, USA \\ Bradley D. Bowen, Ed.D., Virginia Tech, USA \\ Thomas O. Williams, Ph.D., Virginia Tech, USA
}

\begin{abstract}
Students identified as at-risk of non-academic continuation have a propensity toward lower academic self-efficacy than their peers (Lent, 2005). Within engineering, self-efficacy and confidence are major markers of university continuation and success (Lourens, 2014 Raelin, et al., 2014). This study explored academic learning self-efficacy specific to first-year engineering students with at-risk indicators. The at-risk determination was made through trajectory to matriculate, classified by cumulative grade point average of academic studies. An adapted version of the Self-efficacy for Learning (SEL) scale, modified by Klobas, Renzi and Nigrelli (2007), was administered to freshman engineering students identified at-risk and not at-risk of matriculation. Internal consistency of the SEL was analyzed and once deemed satisfactory (Cronbach alpha $=.94)$, item-level outcome comparisons between student subgroups were made for each of the 22 instrument items.
\end{abstract}

Keywords: At-Risk; Freshman Engineering; Self-Efficacy for Learning; Academic Self-Efficacy

\section{INTRODUCTION}

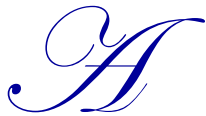

lthough there are many factors that affect student success, Lent, Brown and Hackett (1994) proposed that environmental, personal and behavioral factors outlined in Bandura's Social Cognitive Theory (1986) combine to impact academic persistence and outcome. Pertaining to goals and success, a focal component within individualized personal factors is self-efficacy (Akbulut \& Looney, 2009). Self-efficacy is not based on cognitive abilities, but merely as an indicator of how strongly that students believe they can master the task at hand. According to Bandura (1982), self-efficacy has four major sources of information:

1. Enactive Mastery Experience, perhaps the most influential, as past experiences in a domain shape the foundations for those to follow.

2. Vicarious experiences, these are present when a student has no previous experience in a domain. Watching other students struggle in an unfamiliar subject may hinder the students' success.

3. Verbal persuasion, in the form of positive feedback does much to increase a students' self-efficacy.

4. Physiological reactions, observation of physiological reaction, especially negative reactions such as sweating, excessive heart rate, etc, can have an effect on self-efficacy.

Bumann \& Younkin (2012) stated that "Bandura's theory of self-efficacy can be used as a tool to reinforce ability and promote capability in successful attainment of new skills. Understanding the process of acquiring efficacy while practicing new skills and behaviors will increase resilience and endurance in the face of setbacks" (pg. 12).

Studies, however, have shown that there is more to self-efficacy than mere felicity of being. Self-efficacy has also been shown to be an accurate predictor of students' performance (Bandura, 1977) and engineering students' intentions to persist (Concannon \& Barrow, 2010; Hsieh, Sullivan, Sass, \& Guerra, 2012; Lent, Brown, \& Larkin, 1986). "In a long line of published research, efficacy beliefs have been shown to contribute independently to performance rather than simply reflect cognitive abilities" (Maier \& Curtin, 2005, p.354). 
Academic self-efficacy is the personal estimation of how a student feels about how well they will succeed in any given academic setting. The rigorous nature of engineering programs illustrates the importance of self-efficacy in one's ability to negotiate major academic milestones in an engineering program (Lent, Brown, \& Larkin, 1986). A student's confidence in their abilities to complete the core engineering requirements is of vital importance to success (Hackett \& Lent, 1992), not only in college, but also in career choice (Betz and Hackett 1981; Lent, Brown, \& Larkin, 1986). Student persistence in engineering programs is not tied to any one construct. Self-efficacy affects performance in a complex arena of personal and situational factors that affect the choices the student has to make when given any task. Task difficulty, the estimated amount of effort, the estimated amount of help one might receive, and previous patterns of success and failure all are constructs when building self-efficacy (Schunk, 1983; Maddux, 1995; Pajares, 1996; Stajkovic \& Luthans, 1998, as cited in Rawlings, 2012, p.554). Other self-efficacy constructs such as coping self-efficacy and career outcome expectations have a direct relationship to persistence and students' intentions to persist (Concannon and Barrow 2010; Hackett \& Lent, 1992; Hsieh, Sullivan, Sass, \& Guerra, 2012; Larson et al., 2014; Mau 2003; Concannon \& Barrow, 2012).

While the importance of learning in complex skillsets such as engineering cannot be denied, rigorous programs must understand how and why students remain motivated during the process and see it to completion. A study of cognition, as well as self-efficacy is important to understand the facilitation or hindrance of learning in engineering education. (Carberry, Hee-Sun, and Ohland, 2010, p.71). Wood and Locke (1987) showed a "profound" effect of self-efficacy on the performance of college students. Self-efficacy in learning is not only present in the student, but drives a student to be a lifelong learner, especially in making choices for the future about learning opportunities (Klobas, Renzi \& Nigrelli, 2007). "Students' experiences at university prepare them for a future in which they are expected to engage in life-long learning. Self-efficacy theory suggests that a person's beliefs in their capacity to learn will influence their participation in learning" (Klobas, Renzi, \& Nigrelli, 2007, p.3).

At-risk students may be even more susceptible to factors of self-efficacy than those deemed not at-risk. In a 2005 study, those students deemed at-risk reported lower academic self-efficacy scores than those students not reported as at-risk (Lent, 2005). At-risk students with high self-efficacy were found to fail fewer classes during their senior year (Wood \& Locke, 1987). At-risk students also tend to have goals that are non-academic in nature (Carroll, et al, 2013). While half of engineering students in the United States drop out within the first two years (Crawford \& Schmidt, 2004), socio-economic status of the students has been reported to be a high factor when predicting success of the student (Guner, Yaldir, Gunduz, Comak, Tokat, \& Iplikci, 2014). It is equally important that we study at-risk students and self-efficacy, especially in challenging domains such as engineering. While these two factors are not the only clear predictors of success, an educator has no control over whether a student is at-risk. If an educator can identify self-efficacy issues in a student early enough, there are strategies that can be installed to change the motivation, or lack thereof, in freshman engineering students.

\section{RESEARCH QUESTIONS}

This study examined similarities and separations of self-efficacy for academic learning among freshman engineering students identified as at-risk of non-matriculation and students with satisfactory matriculation status, as determined by cumulative grade point average (GPA). This research was designed to connect and build upon existing STEM education and engineering self-efficacy research, as well as research on at-risk indicators for post-secondary students. The following overarching research question guided this study: Is there an identifiable difference between academic learning self-efficacy of freshman engineering students identified at-risk and not at-risk of matriculation?

\section{STUDY PARTICIPANTS}

The participants in this study included students enrolled in the College of Engineering (CoE) at a university in the upper Midwest. The sample was taken from the population of students that were enrolled as freshman in the $\mathrm{CoE}$ during 2012-2013 and the 2013-2014 academic years. The classification of the student is determined by the total number of credit hours completed at the time of enrollment, which is indicated on their transcript. At this university, students are classified by the following number of credit hours; freshman (0-29), sophomore (30-59), junior (60-89) and senior $(90+)$. Overall enrollment based on classifications determined by credit hour completion at the university, indicate engineering attrition patterns. Figure 1 represents the number of students enrolled in the CoE for each 
cohort year from fall of 2010 through fall of 2014. The general trend is that the number of students decreases through each year of the program. However, the number of sophomores in the 2013 cohort is greater than the number of freshman. The numbers for the sophomore year may have increase due to students transferring between departments or students not obtaining the necessary credits to continue matriculating with the majority of the students in their cohort. It is also visually amplified that the number of seniors for the 2010 and 2011 cohorts is more than the number of juniors from that same cohort because this category includes students with greater than 89 completed credits. The 2010 and 2011 bar graphs are inclusive of student numbers from cohorts prior to 2011 that have not fulfilled requirements for graduation, indicating delayed completion for factors unknown. The breakdown of the $201190+$ credit hours data point is composed of the following categorizations: Total seniors as of the fall 2014 4-week official census data as reported by registration and records $=743 ; 90-120$ credits $=379 ; 121-150=$ $263 ; 151-200=86$; and $200+=15$.

Figure 1. Total enrollment in the College of Engineering based on grade level and year as of Fall enrollment

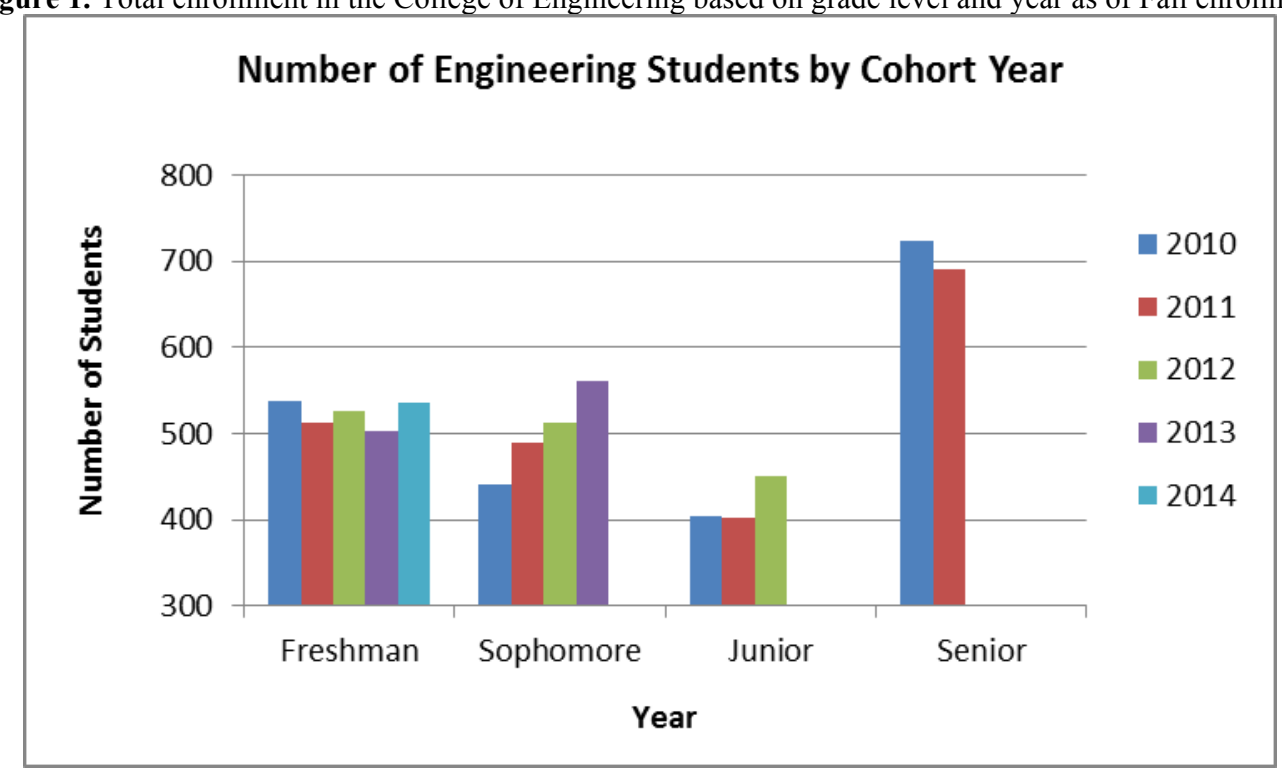

To further describe the structure and enrollment patterns of the university CoE, enrollment in each of the six departments (Agriculture and Biosystems Engineering, Civil Engineering, Construction Management and Engineering, Electrical and Computer Engineering, Industrial and Manufacturing Engineering, and Mechanical Engineering) is reported in Table 1. In addition, the $\mathrm{CoE}$ has a general engineering curriculum for students who have not yet declared a major department within the college. At the beginning of the 2012 and 2013 academic year, there were a total of 525 students and 502 students, respectively, enrolled as freshmen in the CoE. The breakdown of the number of students for each department is shown in Table 1. These numbers also include students who may have transferred from other universities as a sophomore as well as students transferring between departments in the CoE. The numbers for departmental enrollment were obtained from the Student Support Center Director of the University CoE.

Table 1. Number of freshman students enrolled in each engineering department

\begin{tabular}{l|c|c|c|c}
\hline \multicolumn{1}{c|}{ Engineering Department } & Fall 2012 & Fall 2013 & Total & Dept. courses required 1st Yr. \\
\hline Agriculture and Biosystems & 22 & 21 & 43 & 3 \\
\hline Civil & 92 & 84 & 176 & 2 \\
\hline Construction Management and Engineering & 36 & 37 & 73 & 2 \\
\hline Electrical and Computer & 114 & 96 & 210 & 3 \\
\hline Industrial and Manufacturing & 34 & 26 & 60 & 2 \\
\hline Mechanical & 126 & 144 & 270 & 2 \\
\hline General & 101 & 94 & 195 & - \\
\hline Total & 525 & 502 & 1027 & \\
\hline
\end{tabular}


The coursework for the freshman engineering students consists mostly of general education courses for which other university freshman may register. These courses commonly consist of chemistry, mathematics, English or composition, public speaking, and a one credit university skills and academic success course. In addition to these general courses, each engineering department requires two or three departmental specific courses during the freshman year. The number of non-general department specific courses required are also listed in Table 1. These are shown to indicate the level of engagement freshman students have within their department. By the end of their freshman year, each student in the CoE should have completed all the freshman general education courses as well as several departmental courses. After this academic sequence, students with GPAs of lower than 3.0, on a 4-point scale, were categorized as at-risk of non-matriculation within engineering majors.

\section{INSTRUMENTATION}

A theory-based scale developed by Klobas, Renzi and Nigrelli (2007) was adopted in this study to measure selfefficacy for learning (SEL) among university students. The scale was a modification of Wood and Locke's (1987) work. It changed some activities to be adaptive to computer-supported learning environments, and added an extended set of items to represent all levels of Bloom's (1969) taxonomy of educational objectives. In addition, items addressing self-study, peer learning, and information gathering were also taken into account to reflect a more complete set to measure SEL in the computer-based and online learning environments.

The construction of the scale was based on mixed methods philosophies. Two studies were conducted by the developers of this scale during the iterative development process. A sample of 1737 Italian university students and a second sample of 265 were involved in the two studies respectively based on in-progress versions of the scale.

The established final scale was a parsimonious set of 10 items. Each item was measured on an 11 point Likert-scale, ranging from 0 (I am definitely not able to do this) to 10 (I definitely can do this). The scale was judged as good fit to a two factor model through factor analysis. Rasch analysis was conducted to confirm the acceptable item difficulty distribution. The scale was reported as capable of discriminating among university students. A moderately small but significant correlation of .22 was found between the scale measure and students' expected performance in future examinations, suggesting a comparable concurrent validity to Wood and Locke's (1987) original work. The adapted SEL items are display in Table 2.

Table 2. Items of the self-efficacy for learning measure

\begin{tabular}{|c|c|}
\hline Item \# & SEL Items for Response \\
\hline 1 & I am able to organize my activities so that I can meet all course deadlines. \\
\hline 2 & Soon after the end of a lesson, I am able to remember all of the key concepts. \\
\hline 3 & I can understand all of the key concepts covered in my coursework. \\
\hline 4 & I am able to explain to my fellow students, in a way they can understand, all of the key concepts covered in courses. \\
\hline 5 & After sitting for an examination, I am able to remember all of the key concepts covered in courses. \\
\hline 6 & $\begin{array}{l}\text { When I find something new about a topic that I am studying, I am always able to connect it with other things that I } \\
\text { know about the topic. }\end{array}$ \\
\hline 7 & I always know how to get up to date on a topic if my knowledge of it is outdated. \\
\hline 8 & $\begin{array}{l}\text { Even when I haven't participated in a lesson, I can always understand the concepts covered in the lesson by reading a } \\
\text { textbook. }\end{array}$ \\
\hline 9 & I am never embarrassed to ask a teacher for clarification. \\
\hline 10 & I am always able to identify the most appropriate person to help me resolve a problem related to my study. \\
\hline 11 & I am always able to evaluate the quality of fellow group members' contributions when I participate in group activities. \\
\hline 12 & I am always able to relate the notes I have made during a lesson with the topics covered in the course text or readings. \\
\hline 13 & It is always easy for me to understand new information, even on a topic that does not interest me very much. \\
\hline 14 & It is always easy for me to connect new information about a topic that interests me with other pieces of information. \\
\hline 15 & $\begin{array}{l}\text { During a course, if we are given a new task to complete, I can always complete it by applying the knowledge that I } \\
\text { obtained from lessons. }\end{array}$ \\
\hline 16 & $\begin{array}{l}\text { Soon after the end of a lesson, I am always able to distinguish the most important concepts from concepts of less } \\
\text { importance. }\end{array}$ \\
\hline
\end{tabular}




\begin{tabular}{c|l} 
(Table 2 Continued) \\
\hline 17 & $\begin{array}{l}\text { If, as part of a course, I participate in a forum or online discussion, I am always able to identify those messages which } \\
\text { will improve my understanding of the material covered in the course. }\end{array}$ \\
\hline 18 & I always find it easy to join a group of fellow students to study or complete course activities. \\
\hline 19 & I am always able to use the library and library services to select appropriate books and articles for an assignment. \\
\hline 20 & $\begin{array}{l}\text { After a lesson, I am always able to integrate concepts described by the teacher with those presented in course texts and } \\
\text { readings. }\end{array}$ \\
\hline 21 & When I write an essay for a course, I am always able to incorporate knowledge gained from other sources. \\
\hline 22 & I am always able to help other students solve problems based on concepts described in a lesson. \\
\hline
\end{tabular}

\section{METHODOLOGY}

The method and approach for this project regarding data collection is similar to the study by Ernst and Bowen (2014). The current study was performed over two years and included freshman students, as defined by the number of credit hours, from both the Fall 2012 and Fall 2013 records. The researchers initially obtained an email listing of all the students on the freshman listserv for these semesters from the Office of Registration and Records. For participant recruitment, an email with a hyperlink to the electronic survey was sent to each student on the list. The first page of the survey contained informed consent by summarizing the project and the purpose of the research, explaining how participation in the research project by completing the survey was voluntary, and asked each willing participant to verify they were at least 18 years of age. The survey was sent to group 1, freshman during the 20122013 school year, during the spring semester of their sophomore year. The survey was sent out three times; once approximately four weeks after the start of the semester and then in two week intervals. After the final survey request, the researchers recorded the responses from the survey for data analysis. The survey was sent to group 2, freshman during the 2013-2014 school year, just prior to and during the beginning of the 2014 fall semester. This would have been the fall semester of their sophomore year. The survey was send out three times; once approximately two weeks before the beginning of the semester and then in two week intervals. After the final survey request, the researchers recorded the responses from the survey for data analysis.

\section{DATA ANALYSIS AND FINDINGS}

Data were analyzed using SPSS 20. For the purposes of this investigation, the 103 participants were divided into two groups: an at-risk group and not at-risk group. The at-risk group was defined as those with a GPA of less than 3.0. The not at-risk group was defined as those with a GPA 3.0 or higher. The at-risk group consisted of 22 students and the not at-risk group consisted of 81 students.

A Cronbach alpha coefficient was calculated for the 22 items selected from the Scale for the Measurement of SelfEfficacy for Learning (SEL) to determine the suitability of the items for statistical analysis. Cronbach's alpha is a measure of internal consistency and how closely related a set of items are as a group. It is a measure of scale reliability. As the 22 items were selected from a longer version of the SEL it was necessary to investigate whether the psychometric properties were adequate for the research questions addressed and the statistical methods employed in this investigation.

Independent sample t-tests were computed to compare the at-risk and not at-risk groups for the total score (sum of the 22 items) to determine whether there was a statistically significant difference between the group's score on GPA. Additionally, t-tests were computed for the 22 individual items to determine whether there were any statistically significant differences between the group's scores at an item level. This procedure resulted in 22 separate t-tests. A probability level of $p \leq .05$ was selected as a measure of statistical significance. In all, 23 separate t-tests were computed to address the research questions comparing the group differences.

The obtained Cronbach alpha coefficient for the 22 item ratings from the SEL was .94 . At the $95 \%$ confidence interval the alpha coefficients for the ratings ranged from .93 to .96 . This indicated that the internal consistency of the test items were adequate for the statistical procedures and research methods used in this study. The overall mean item score for the sample was 6.75 and ranged from 5.71 to 8.36. The mean scores and standard deviations for each of the 22 scale items are presented in Table 3. 
Table 3. Item characteristics for reliability analysis of scale item ratings.

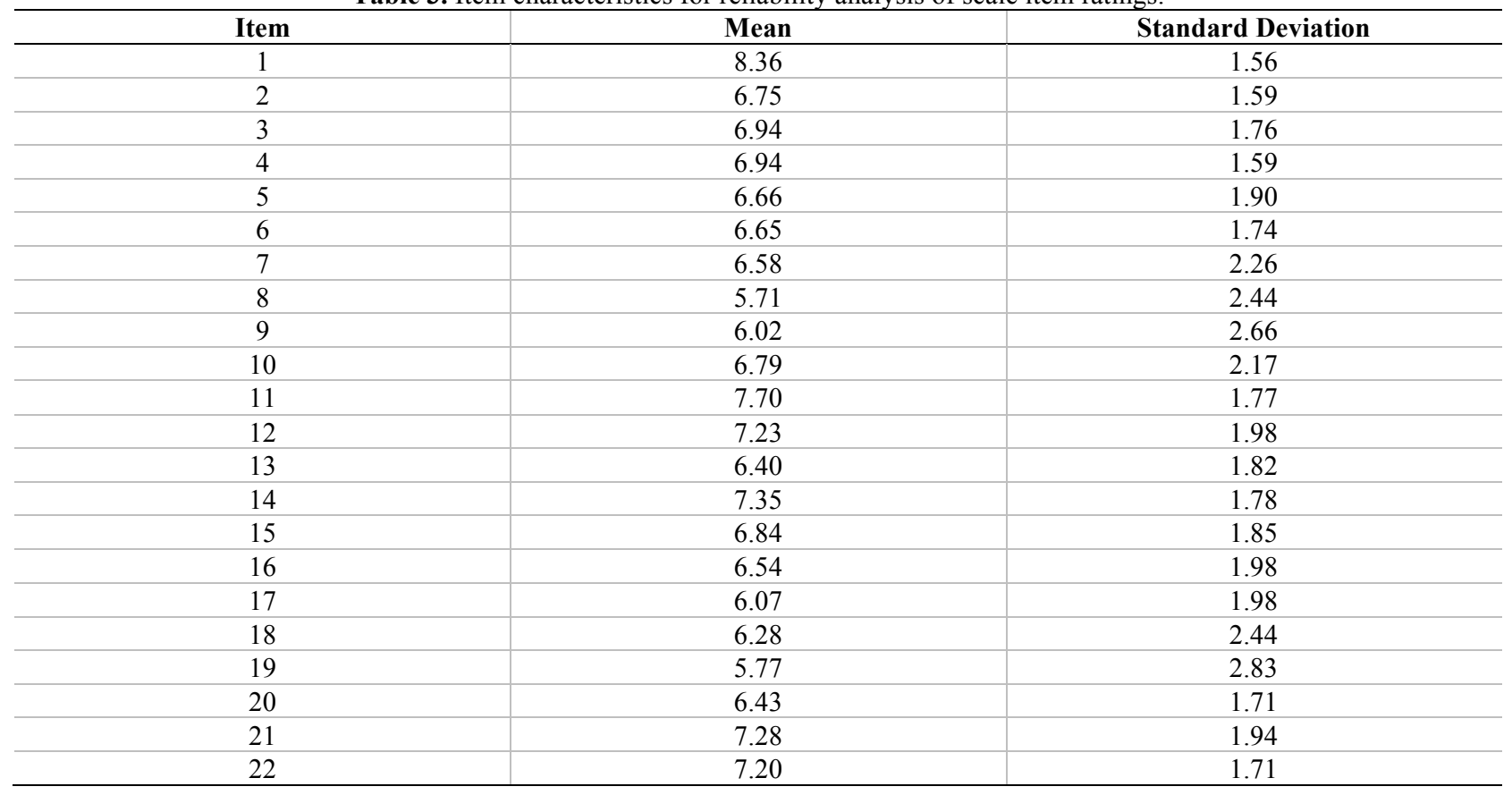

The t-test for the total score between the at-risk and not at-risk students indicated that there was a statistically significant difference between the two group's scores on overall self-efficacy for learning. The results are presented in Table 4.

Table 4. T Test for total score on the Scale for the Measurement of Self-Efficacy for Learning.

\begin{tabular}{l|c|c|c|c|c}
\hline \multicolumn{1}{c}{ Group } & Sample Mean & Standard Error & DF & T-Statistic & P-Value \\
\hline At Risk & 134.12 & 8.33 & 101 & 2.49 & .01 \\
\hline Not at Risk & 152.21 & 2.86 & & & \\
\hline
\end{tabular}

Twenty-two t-tests were conducted on the individual items composing the rating scale. Table 5 presents the results of the t-tests. Of the 22 items, items 1, 2, 5, 13, 14, 16, 20, and 22 were statistically significant at the $p \leq .05$ level of significance level. 
Table 5. T tests for individual items comparing at risk and not at risk student ratings on the SEL

\begin{tabular}{|c|c|c|c|c|c|c|}
\hline Group & Scale Item & Sample Mean & Std. Error & DF & T-Statistic & P-Value \\
\hline At Risk & 1 & 7.23 & .45 & 101 & 4.11 & $<.01$ \\
\hline Not at Risk & & 8.67 & .14 & & & \\
\hline At Risk & 2 & 6.14 & .41 & 101 & 2.06 & .04 \\
\hline Not at Risk & & 6.91 & .16 & & & \\
\hline At Risk & 3 & 6.41 & .41 & 101 & 1.61 & .11 \\
\hline Not at Risk & & 7.09 & .19 & & & \\
\hline At Risk & 4 & 6.55 & .43 & 101 & 1.32 & .19 \\
\hline Not at Risk & & 7.05 & .16 & & & \\
\hline At Risk & 5 & 5.82 & .40 & 101 & 2.40 & .02 \\
\hline Not at Risk & & 6.89 & .21 & & & \\
\hline At Risk & 6 & 6.18 & .42 & 101 & 1.43 & .15 \\
\hline Not at Risk & & 6.78 & .18 & & & \\
\hline At Risk & 7 & 5.91 & .42 & 101 & 1.60 & .12 \\
\hline Not at Risk & & 6.77 & .26 & & & \\
\hline At Risk & 8 & 4.91 & .47 & 101 & 1.75 & .08 \\
\hline Not at Risk & & 5.93 & .27 & & & \\
\hline At Risk & 9 & 5.18 & .57 & 101 & 1.68 & .10 \\
\hline Not at Risk & & 6.25 & .29 & & & \\
\hline At Risk & 10 & 6.27 & .47 & 101 & 1.26 & .21 \\
\hline Not at Risk & & 6.93 & .24 & & & \\
\hline At Risk & 11 & 7.09 & .45 & 101 & 1.84 & .07 \\
\hline Not at Risk & & 7.86 & .18 & & & \\
\hline At Risk & 12 & 6.55 & .48 & 101 & 1.86 & .07 \\
\hline Not at Risk & & 7.42 & .21 & & & \\
\hline At Risk & 13 & 5.50 & .42 & 101 & 2.69 & .01 \\
\hline Not at Risk & & 6.64 & .19 & & & \\
\hline At Risk & 14 & 6.55 & .47 & 101 & 2.45 & .02 \\
\hline Not at Risk & & 7.57 & .18 & & & \\
\hline At Risk & 15 & 6.55 & .45 & 101 & 0.85 & .40 \\
\hline Not at Risk & & 6.93 & .20 & & & \\
\hline At Risk & 16 & 5.55 & .44 & 101 & 2.75 & .01 \\
\hline Not at Risk & & 6.82 & .21 & & & \\
\hline At Risk & 17 & 5.77 & .48 & 101 & 0.79 & .43 \\
\hline Not at Risk & & 6.15 & .21 & & & \\
\hline At Risk & 18 & 5.77 & .54 & 101 & 1.10 & .27 \\
\hline Not at Risk & & 6.42 & .27 & & & \\
\hline At Risk & 19 & 5.55 & .56 & 101 & 0.41 & .68 \\
\hline Not at Risk & & 5.83 & .32 & & & \\
\hline At Risk & 20 & 5.77 & .42 & 101 & 2.05 & .04 \\
\hline Not at Risk & & 6.61 & .18 & & & \\
\hline At Risk & 21 & 7.09 & .50 & 101 & 0.52 & .61 \\
\hline Not At Risk & & 7.33 & .20 & & & \\
\hline At Risk & 22 & 6.50 & .45 & 101 & 2.22 & .03 \\
\hline Not At Risk & & 7.40 & .17 & & & \\
\hline
\end{tabular}

\section{CONCLUSIONS}

Within this study, students who are not categorized as at-risk had collectively higher self-efficacy for learning than the student participants identified as at-risk. Previous academic successes are highlighted within the aforementioned educational theories and prior research studies as an influential feature pertaining to self-efficacy for learning. Based on the study findings and results, it appears that this norm transcends educational levels into that of university freshman engineering as well. However, elements such as grasp of academic material, ability to communicate academic material, academic collaboration, and acquisition of academic support resources/materials do not persist in this regard. High self-efficacy can lead to resolution, confidence, determination, and in this study, enriched matriculation standing based upon academic performances. 
Self-efficacy, has been shown to help students persist longer on tasks, set attainable goals, and provide a general sense of well-being as a person and as a student (Bong \& Skaalvik, 2003). Bumann and Younkin (2012, p.11) characterize the impacts of self-efficacy best with the following statement:

"People with a sense of self-efficacy believe in their ability and capability to succeed in attaining their goals. A sense of efficacy provides staying power and resilience to endure and move beyond obstacles and setbacks, and allows for a creative response to failure and disappointment. Individuals with high selfefficacy view failures and disappointments as indicators of the need to learn more or to use different problem-solving strategies. In the absence of self-efficacy, such challenges are more likely to be seen as personal flaws or lack of ability" (Bumann \& Younkin, 2012, p.11).

\section{AUTHOR BIOGRAPHIES}

Jeremy V. Ernst is Director of the Office of Educational Research and Outreach at Virginia Tech, Associate Professor in the Integrative STEM Education program, and a Faculty Fellow at the Institute for Creativity Arts and Technology. Jeremy specializes in research focused on dynamic intervention means for STEM education students categorized as at-risk of dropping out of school. He also has curriculum research and development experiences in technology, engineering, and design education.

Bradley D. Bowen is an Assistant Professor of Integrative STEM Education at Virginia Tech. His background includes both industry engineering work and technology education classroom teaching experience. He specializes in professional development for K-12 teachers in STEM and Engineering Education as well as developing and integrating project-based activities into the K-12 classroom.

Thomas O. Williams Jr. is an associate professor in the Special Education Program at Virginia Tech. His educational background includes degrees in psychology and special education/rehabilitation. He specializes in research focused on emotional/behavioral disorders, test development, and psychoeducational assessment.

\section{REFERENCES}

Akbulut, A. Y., \& Looney, C. A. (2009). Improving IS student enrollments: Understanding the effects of IT sophistication in introductory IS courses. Journal of Information Technology Education, 887-100.

Bandura, A. (1977). Self-efficacy: toward a unifying theory of behavioral change. Psychological review, 84(2), 191.

Bandura, A. (1982). Self-efficacy mechanism in human agency. American Psychologist, 37, 122-147.

Bandura, A. (1986). Social foundation of thought and action: A social cognitive theory. Englewood Cliffs, NJ: Prentice Hall.

Betz, N.E. \& Hackett, G. (1983). The relationship of mathematics self-efficacy expectations to the selection of science-based college majors. Journal of Vocational Behavior, 23, 329-345.

Bloom, B. S. (1969). Taxonomy of Educational Objectives: The Classification of Educational Goals (Vol. Handbook I, Cognitive Domain.) London: Longman.

Bong, M., \& Skaalvik, E. M. (2003). Academic self-concept and self-efficacy: How different are they really? Educational psychology review, 15(1), 1-40.

Bumann, M., \& Younkin, S. (2012). Applying self efficacy theory to increase interpersonal effectiveness in teamwork. Journal of Invitational Theory \& Practice, 18(1), 11-18.

Carberry, A. R., Hee-Sun, L., \& Ohland, M. W. (2010). Measuring engineering design self-efficacy. Journal of Engineering Education, 99(1), 71-79.

Carroll, A., Gordon, K., Haynes, M., \& Houghton, S. (2013). Goal setting and self-efficacy among delinquent, at-risk and not atrisk adolescents. Journal of Youth and Adolescence, 42(3), 431-443. doi:10.1007/s10964-012-9799-y

Concannon, J. P., \& Barrow, L. H. (2012). A reanalysis of engineering majors' self-efficacy beliefs. Journal of Science Education and Technology, 21(6), 742-753.

Crawford, M \& Schmidt, K..J. Lessons Learned from a K-12 Project. Proceedings of the 2004 American Society for Engineering Education Annual Conference and Exposition, Washington, American Society for Engineering Education, pp. 1-13, 2004.

Ernst, J. V. \& Bowen, B. D. (2014). Career awareness of freshman engineering students academically at-risk. American Journal of Engineering Education, 5(2), 91-98.

Guner, N., Yaldir, A., Gunduz, G., Comak, E., Tokat, S., \& Iplikci, S. (2014). Predicting academically at-risk engineering students: A soft computing application. Acta Polytechnica Hungarica, 11(5), 199-216.

Hackett, G., \& Lent, R. W. (1992). Theoretical advances in career psychology. In S. D. Brown \& R. W. Lent (Eds.), Handbook of 
counseling psychology (2nd ed., (pp. 419-452). New York: Wiley.

Hsieh, P., Sullivan, J., Sass, D., \& Guerra, N. (2012). Undergraduate engineering students' beliefs, coping strategies, and academic performance: an evaluation of theoretical models. The Journal of Experimental Education, 80(2), $196-218$.

Klobas, J. E., Renzi, S., \& Nigrelli, M. L. (2007). A scale for the measurement of self-efficacy for learning (SEL) at university (Dondena Working Paper No. 2). Milan: Carlo F Dondena Centre for Research on Social Dynamics.

Larson, L., Pesch, K., Surapaneni, S., Bonitz, V., Wu, T., \& Werbel, J. (2014). Predicting graduation: the role of mathematics/science self-efficacy. Journal of Career Assessment. DOI: 1069072714547322.

Lent, P. K. (2005). At-risk students and self-efficacy (Order No. 1429970). Available from ProQuest Dissertations \& Theses Global. (305361625). Retrieved from http://ezproxy.lib.vt.edu:8080/login?url=http://search.proquest.com/docview/305361625?accountid=14826

Lent, R. W., Brown, S. D., \& Larkin, K.C. (1986). Self-efficacy in the prediction of academic performance and perceived career options. Journal of Counseling Psychology, 38, 424-430.

Lent, R. W., Brown, S. D., \& Hackett, G. (1994). Toward a unifying social cognitive theory of career and academic interest, choice, and performance. Journal of Vocational Behavior, 45, 79-122.

Lourens, A. (2014). The development of co-curricular interventions to strengthen female engineering students' sense of selfefficacy and to improve the retention of women in traditionally male-dominated disciplines and careers. South African Journal of Industrial Engineering, 25(3), 112-125.

Maier, S. R., \& Curtin, P. A. (2005). Self-efficacy theory: A prescriptive model for teaching research methods. Journalism \& Mass Communication Educator, 59(4), 352-364.

Mau, S. (2003). The moral economy of welfare states: Britain and Germany compared. London: Routledge.

Raelin, J. A., Bailey, M. B., Hamann, J., Pendleton, L. K., Reisberg, R., \& Whitman, D. L. (2014). The gendered effect of cooperative education, contextual support, and self-efficacy on undergraduate retention. Journal of Engineering Education, 103(4), 599-624.

Rawlings, M. A. (2012). Assessing BSW student direct practice skill using standardized clients and self-efficacy theory. Journal of Social Work Education, 48(3), 553-576.

Schunk, D. H. (1983). Developing children's self-efficacy and skills: The roles of social comparative information and goal setting. Contemporary Educational Psychology, 8(1), 76-86.

Wood, R. E., \& Locke, E. A. (1987). The relation of self-efficacy and grade goals to academic performance. Educational and psychological measurement, 47, 1013-1024. 
NOTES 